Огляди літератури, оригінальні дослідження, погляд на проблему

УДК 612.015.11-02:616.71/72-018.3-007.248-06:616.37-008.64

DOI 10.11603/1811-2471.2017.v1.i3.8099

\title{
ЗОВНІШНЬОСЕКРЕТОРНА НЕДОСТАТНІСТЬ ПІДШЛУНКОВОЇ ЗАЛОЗИ ТА ДИСБАЛАНС СИСТЕМИ ПРООКСИДАНТИ-АНТИОКСИДАНТИ ПРИ ПЕРВИННОМУ ОСТЕОАРТРОЗІ 3 КОМОРБІДНИМИ СТАНАМИ
}

\author{
๑л. С. Бабінець, І. М. Галабіцька, Т. Г. Маєвська
}

ДВНЗ «Тернопільський державний медичний університет імені І. Я. Горбачевського МОЗ України»

РЕЗЮМЕ. У статті розглянуті сучасні погляди на проблему коморбідності первинного остеоартрозу і захворювань, що супроводжуються порушенням зовнішньосекреторної функції підшлункової залози. Проаналізовано рівень активації оксидативного стресу і ослаблення ферментної і неферментної ланок антиоксидантної системи захисту, а також досліджено дефект трофологічного статусу у вітамінній складовій. Дослідниками було встановлено, що найвищий рівень активації процесів пероксидації спостерігався у пацієнтів 3 первинним остеоартрозом у поєднанні із захворюваннями, що супроводжуються порушенням зовнішньосекреторної функції підшлункової залози. Рівні ферментних і неферментних антиоксидантів були статистично значимо знижені у всіх групах пацієнтів, порівняно з контролем, проте у пацієнтів з первинним остеоартрозом у поєднанні із захворюваннями, що супроводжуються порушенням зовнішньосекреторної функції підшлункової залози, рівні антиоксидантів були статистично значимо найнижчими, порівняно з іншими групами, що свідчить про поглиблення дефіциту показників антиоксидантної системи захисту при коморбідності. Також виявлено поглиблення дефекту трофологічного статусу у вітамінній складовій (токоферол, ретинол, аскорбінова кислота) при коморбідності первинного остеоартрозу із захворюваннями, що супроводжуються порушенням зовнішньосекреторної функції підшлункової залози.

КлючовІ СлОвА: первинний остеоартроз; порушення зовнішньосекреторної функції підшлункової залози; трофологічний статус.

Вступ. Остеоартроз (ОА), його клінічний перебіг та формування програм реабілітації хворих з цією патологією часто стають об'єктом уваги науковців і практиків в силу суттєвої поширеності у світі та високого рівня інвалідизації пацієнтів із цією патологією. За даними National Health and Nutrition Examination Survey (NHANE), суглобова патологія займає третє місце за поширеністю серед хронічних станів у осіб віком понад 65 років. Поширеність ОА підвищується з кожним роком. За результатами епідеміологічних досліджень у США, протягом останнього десятиліття вона зросла 3 21 до 27 млн осіб серед дорослого населення [4]. Згідно з сучасними даними, ОА охоплює гетерогенну групу захворювань різної етіології, але з подібними біологічними, морфологічними і клінічними проявами і наслідками, в основі яких лежить ураження всіх компонентів суглобів, насамперед суглобового хряща, а також субхондральної кістки, синовіальної оболонки, зв'язок, капсули суглоба і періартикулярних м'язів. Поряд із прогресуючим ураженням суглобів, функціональними обмеженнями, труднощами у виконанні повсякденної діяльності, зниженням якості життя найхарактернішими проявами захворювання $\epsilon$ хронічний больовий синдром [5]. Однією з ланок патогенезу ОА $\epsilon$ підсилення оксидативного стресу (ОС) і ослаблення антиоксидантної системи захисту (АОСЗ). Деякі автори відзначають, що посилена оксидація при ОА викликає інтенсивне утворення вільних радикалів (перекису водню, супер- оксидного аніона, гідроксильного радикала), а вони, своєю чергою, ініціюють зміни макромолекул білків, жирів, вуглеводів. Вільні радикали викликають деполімеризацію глікозаміногліканів, у тому числі гіалуронової кислоти, та руйнування колагенових структур, спричиняючи таким чином пошкодження хряща. Вони також пригнічують проліферацію хондроцитів і посилюють протеоліз міжклітинної речовини хряща за рахунок активності протеолітичних ферментів в умовах патології [2]. За останні роки встановлено, що коморбідна патологія істотно погіршує порушення фізичної функції та спричиняє вищу смертність у хворих на ОА. Дослідження також виявили високу частоту при ОА захворювань шлунково-кишкового тракту (ШКТ), особливо тих, що супроводжуються порушенням зовнішньосекреторної функції підшлункової залози (ПЗ), що також сприяє розбалансуванню системи прооксиданти-антиоксиданти $[1,2]$. Зовнішньосекреторна недостатність ПЗ (ЗСНПЗ) при ОА формується як внаслідок коморбідних патологій, для яких вона притаманна (хронічний панкреатит із ЗСН ПЗ та формуванням інкреторної недостатності у формі цукрового діабету (ЦД), функціональні біліарні порушення, захворювання печінки та жовчовивідної системи, хвороби гастродуоденальної зони, ентероколіт та дисбіоз кишечника), так і внаслідок довготривалого лікування ОА з використанням нестероїдних протизапальних препаратів, глюкокортикоїдів, хондропротекторів і хондростимуляторів та 
Огляди літератури, оригінальні дослідження, погляд на проблему

ін. У зв'язку з вищенаведеним вважаємо актуальним дослідити стан системи прооксиданти-антиоксиданти при перебігу ОА на тлі ЗСНПЗ, оскільки ці взаємодіючі фактори та ризики потребують їхнього урахування при узгодженні комплексної терапії та реабілітації таких хворих.

Мета роботи - вивчити глибину порушень у системі прооксиданти-антиоксиданти у хворих на первинний ОА на тлі порушення у них зовнішньосекреторної функції підшлункової залози.

Матеріал і методи дослідження. Було о6стежено 32 амбулаторних пацієнти з первинним ОА (I група) і 37 - з первинним ОА у поєднанні із захворюваннями, що супроводжуються ЗСНПЗ (II група). Критеріями виключення були онкологічні захворювання, гострі та загострення хронічних патологій життєво важливих органів, тяжкий ЦД, ЦД 1 типу, активні виразки шлунка та дванадцятипалої кишки, вірусні гепатити та цирози печінки, хвороба Крона, неспецифічний виразковий коліт, муковісцидоз. Вік хворих становив від 29 до 74 років. Контрольну групу складали 20 здорових людей. Діагноз первинного ОА встановлювали на основі уніфікованих діагностичних критеріїв, рентгенологічну стадію первинного ОА - за J. H. Kellgren i J. S. Lawrence [3]. Ступінь ЗСНПЗ визначали за рівнем фекальної еластази-1, яку визначали методом імуноферментного аналізу за допомогою стандартних наборів фірми Bioserv Elastase-1-Elisa. Стан ОС оцінювали за рівнем малонового альдегіду (МА), стан (АОСЗ) - за рівнями супероксиддисмутази (СОД), каталази, SH-груп, токоферолу, ретинолу (визначали спектрофотометричним методом) та аскорбінової кислоти (визначали за методикою Фармера).

Результати й обговорення. Аналіз отриманих показників рівнів фекальної еластази-1 у групах дослідження показав наявність ЗСНПЗ в обох

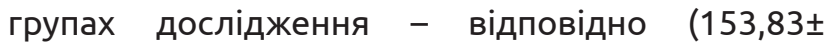
$5,34)$ мкг/г і $(58,65 \pm 4,73)$ мкг/г, порівняно з групою контролю $((213 \pm 6,29)$ мкг/г), а також статистично достовірно нижчий рівень фекальної еластази у II групі, порівняно з таким у I групі $(p<0,05)$. Це констатувало наявність більш глибокого порушення екскреторної функції ПЗ (тяжкого ступеня) при ОА з коморбідними патологіями ШКТ із ЗСНПЗ, а також наявність ЗСНПЗ легкого ступеня у I групі хворих на ОА. Це підтверджує думку про необхідність дослідження цієї проблеми для урахування фактора наявності ЗСНПЗ з метою формування ефективного комплексу реабілітації хворих на ОА з коморбідними патологіями ШКТ.

У ході дослідження було встановлено, що найвищий рівень активації ОС за рівнем МА спостерігався у пацієнтів з первинним ОА на тлі $3 \mathrm{CH} 3$, хоча й у I групі ОС також був суттєвим (табл. 1).

Таблиця 1. Стан показників ОС-АОСЗ у хворих на ОА груп дослідження залежно від наявності ЗСНП3

\begin{tabular}{|l|c|c|c|}
\hline \multirow{2}{*}{ Показник ОС-АОС3 } & \multicolumn{2}{|c|}{ Група дослідження } \\
\cline { 2 - 4 } & група контролю $(\mathrm{n}=20)$ & I група $(\mathrm{n}=32)$ & II група (n=37) \\
\hline МА, ммоль/л & $2,8 \pm 0,09$ & $4,6 \pm 0,12^{*}$ & $43,2 \pm 1,37^{* *}$ \\
\hline СОД, ум. од. & $62,1 \pm 2,85$ & $51,4 \pm 0,77^{*}$ & $13,9 \pm 0,78^{* *}$ \\
\hline Каталаза, \% & $17,5 \pm 0,77$ & $15,7 \pm 0,43^{*}$ & $44,1 \pm 1,29 * *$ \\
\hline SН-групи, ммоль/л & $68,5 \pm 2,13$ & $55,4 \pm 1,93^{*}$ & $59,5 \pm 1,73^{* *}$ \\
\hline Токоферол, мкмоль/л & $113,1 \pm 0,24$ & $82,1 \pm 1,43^{*}$ & $0,6 \pm 0,21^{* *}$ \\
\hline Ретинол, мкмоль/л & $1,6 \pm 0,10$ & $1,2 \pm 0,09^{*}$ & $3,2 \pm 0,16^{* *}$ \\
\hline Аскорбінова кислота, мг/л & $10,3 \pm 0,14$ & $8,4 \pm 0,08^{*}$ & \\
\hline
\end{tabular}

Примітки:1. * - статистично значима різниця показників стосовно групи контролю $(p<0,05)$;

2. * - статистично значима різниця показників II клінічної групи стосовно I групи $(p<0,05)$.

Рівні ферментних і неферментних антиоксидантів (табл. 1) були статистично значимо знижені у всіх групах пацієнтів, порівняно з контролем. Проте у пацієнтів з ОА у поєднанні із захворюваннями, що супроводжуються порушенням зовнішньосекреторної функції ПЗ, рівні антиоксидантів були статистично значимо нижчими, порівняно 3 такими у I групі, що довело наявність поглиблення дефіциту показників АОСЗ при коморбідності. Також виявлено поглиблення дефекту трофологічного статусу у вітамінній складовій (токоферол, ретинол, аскорбінова кислота) при комор- бідності первинного ОА із захворюваннями ШКТ із ЗСНПЗ $(p<0,05)$.

Висновки: 1. Доведено наявність більш глибокого порушення екскреторної функції підшлункової залози (тяжкого ступеня) при ОА з коморбідними патологіями ШКТ із ЗСНПЗ, а також наявність ЗСНПЗ легкого ступеня у I групі хворих на OA.

2. У хворих на первинний ОА, що перебігав ізольовано або у поєднанні із захворюваннями, що супроводжуються порушенням зовнішньосекреторної функції підшлункової залози, було 
Огляди літератури, оригінальні дослідження, погляд на проблему

встановлено стан персистуючого оксидативного стресу за рівнем малонового альдегіду, який перебігав на тлі зниженого рівня антиоксидантів ферментного та неферментного складу $(p<0,05)$.

3. Дефіцит АОСЗ поглиблювався при ОА з наявним зниженням зовнішньосекреторної функції підшлункової залози, що свідчить про поглиблення явищ ОС і ослаблення АОСЗ при поєднанні патологій.

4. Було встановлено дефект трофологічного статусу у вітамінній складовій (токоферол, ретинол, аскорбінова кислота $(p<0,05))$ при коморбід-

\section{ЛІТЕРАТУРА}

1. Бабінець Л. С. Взаємозв'язок стану кісткової тканини, параметрів анемії та білкового статусу при хронічному панкреатиті / Л. С. Бабінець // Український морфологічний альманах. - 2008. - Т. 6, № 3. - С. 93-95.

2. Бабінець Л. С. Клініко-патогенетичні аспекти остеодефіциту при остеоартрозі у поєднанні з хронічним панкреатитом / Л. С. Бабінець, Т. Г. Маєвська // Здобутки клінічної та експериментальної медицини. - 2017. № 2. - С. 31-37.

\section{REFERENCES}

1. Babinets, L.S., (2008). Vzayemozvyazok stanu kistkovoyi tkanyny, parametriv anemiyi ta bilkovoho statusu pry khronichnomu pankreatyti [Relationship of the state of bone tissue, anemia and protein status in chronic pancreatitis]. Ukrayinskyy morfolohichnyy almanakh - Ukrainian Morphological Almanac., 6 (3), 93-95 [in Ukrainian].

2. Babinets, L.S., Maevska, T.G., (2017). Kliniko-patohenetychni aspekty osteodefitsytu pry osteoartrozi u poyednanni z khronichnym pankreatytom. [Clinical and pathogenetic aspects of osteodyphritis in osteoarthritis in combination with chronic pancreatitis]. Zdobutky klinichnoyi ta eksperymentalnoyi medytsyny - Achievements of clinical and experimental medicine, 2, 31-37 [in Ukrainian]. ності первинного ОА із захворюваннями із наявною зовнішньосекреторною недостатністю підшлункової залози.

Перспективи подальших досліджень полягають у поглибленому вивченні трофологічного статусу хворих на ОА у поєднанні із захворюваннями, що супроводжуються порушенням зовнішньосекреторної функції підшлункової залози, що доповнить уявлення про патогенез захворювань і дасть можливість прогнозувати їх перебіг та запропонувати оптимальні схеми лікування.

3. Уніфікований клінічний протокол первинної, вторинної (спеціалізованої) медичної допомоги та медичної реабілітації / Міністерство охорони здоров'я України 10.09.2014, № 638.

4. Subchondral bone as a key target for osteoarthritis treatment / S. Castaneda, J. A. Roman-Blas, R. Largo [et al.] // Biochem. Pharmacol. - 2012. - № 83. - P. 315-323.

5. Hochberg M. Osteoarthritis year 2012 in review: clinical / M. Hochberg // Osteoarthritis Cartilage. - 2012. - № 20. - P. 1465-1469.

3. Unifikovanyy klinichnyy protokol pervynnoyi, vtorynnoyi (spetsializovanoyi) medychnoyi dopomohy ta medychnoyi reabilitatsiyi / Ministerstvo okhorony zdorovya Ukrayiny 10.09.2014, № 638. - Unified clinical protocol of primary, secondary (specialized) medical aid and medical rehabilitation / Ministry of Health of Ukraine 09/10/2014, № 638 [in Ukrainian].

4. Castaneda, S., Roman-Blas, J. A., Largo, R. et al. (2012). Subchondral bone as a key target for osteoarthritis treatment. Biochem. Pharmacol., 83, 315-323.

5. Hochberg, M., (2012). Osteoarthritis year 2012 in review: clinical. Osteoarthritis Cartilage., 20, 1465-1469. 
Огляди літератури, оригінальні дослідження, погляд на проблему

\title{
ВНЕШНЕСЕКРЕТОРНАЯ НЕДОСТАТОЧНОСТЬ ПОДЖЕЛУДОЧНОЙ ЖЕЛЕЗЫ И ДИСБАЛАНС СИСТЕМЫ ПРООКСИДАНТЫ-АНТИОКСИДАНТЫ ПРИ ПЕРВИЧНОМ ОСТЕОАРТРОЗЕ С КОМОРБИДНЫМИ СОСТОЯНИЯМИ
}

\author{
๑л. С. Бабинец, И. М. Галабицкая, Т. г. Маевская
}

ГВУз «Тернопольский государственный медицинский университет имени И. Я. Горбачевского МОЗ Украины»

РЕЗЮМЕ. В статье рассмотрены современные взгляды на проблему коморбидности первичного остеоартроза и заболеваний, сопровождающихся нарушением внешнесекреторной функции поджелудочной железы. Проанализирован уровень активации оксидативного стресса и ослабления ферментного и неферментного звеньев антиоксидантной системы защиты, а также исследованы дефект трофологического статуса в витаминной составляющей. Исследователями было установлено, что высокий уровень активации процессов пероксидации наблюдался у пациентов с первичным остеоартрозом в сочетании с заболеваниями, сопровождающимися нарушением внешнесекреторной функции поджелудочной железы. Уровни ферментных и неферментных антиоксидантов были статистически значимо снижены во всех группах пациентов, по сравнению с контролем. Однако у пациентов с первичным остеоартрозом в сочетании с заболеваниями, сопровождающимися нарушением внешнесекреторной функции поджелудочной железы, уровни антиоксидантов были статистически значимо ниже, по сравнению с другими группами, что свидетельствует об углублении дефицита показателей антиоксидантной системы защиты при коморбидности. Также обнаружено углубление дефекта трофологичного статуса в витаминной составляющей (токоферол, ретинол, аскорбиновая кислота) при коморбидности первичного остеоартроза с заболеваниями, сопровождающимися нарушением внешнесекреторной функции поджелудочной железы.

КЛЮчЕВЫЕ СЛОВА: первичный остеоартроз; нарушения внешнесекреторной функции поджелудочной железы; трофологический статус.

\section{PANCREAS EXTERNAL SECRETION INSUFFICIENCY AND DISBALANCE OF THE PROOXIDANT-ANTIOXIDANT SYSTEMS IN PATIENTS WITH PRIMARY OSTEOARTHROISIS WITH COMORBID PATHOLOGIES}

\author{
@L. S. Babynets, I. M. Halabitska, T. H. Mayevska \\ I. Horbachevsky Ternopil State Medical University
}

SUMMARY. The article considers modern views on the problem of comorbidity of primary osteoarthritis and diseases that are accompanied by a violation of the external secretion function of the pancreas. The level of activation of oxidative stress and weakening of the enzyme and non-enzyme components of the antioxidant system of protection have been analyzed, and the deficiency of the trophological status in the vitamin component has been investigated. The researchers found that the highest level of activation of peroxidation processes was observed in patients with primary osteoarthrosis, in combination with diseases that are accompanied by a violation of the external secretion function of the pancreas. The levels of enzyme and non-enzyme antioxidants were statistically significantly lower in all groups than in control, but in patients with primary osteoarthrosis combined with diseases that were accompanied by a violation of the external secretion function of the pancreas, the antioxidant levels were statistically significantly lower compared to other groups indicates an increase in the deficit of indicators of antioxidant protection system in comorbidity. Deepening of the deficiency of the trophological status in the vitamin component (tocopherol, retinol, ascorbic acid) with the comorbidity of the primary osteoarthrosis with diseases accompanied by a violation of the external secretion function of the pancreas was also detected.

KEY WORDS: primary osteoarthritis; disorders of the exocrine function of the pancreas; trophic status. 